\title{
Perspectives
}

\section{Is English Cinderella, a Kidnapped or Adopted Child, or Godzilla? Diverse Perspectives and Pedagogical Conflicts}

\author{
Hideo Horibe \\ Hiroshima Institute of Technology
}

This paper reviews recent literature in both English and Japanese addressing issues concerning the spread of English as an international language. It categorizes diverse perspectives on this subject in accordance with a set of metaphors: Cinderella, a kidnapped or adopted child, and the monster Godzilla ' The paper then highlights some pedagogical conflicts derived from this diversity of perspectives and closely examines how such conflicts are reflected in the teaching of English in the Japanese education system In conclusion, the author suggests that this set of metaphors can provide a good framework for discussing the future direction of English education in Japan.

本諭は国際語としての英語の広がりに関する諸問題に言及した英語と日本語の最近の文

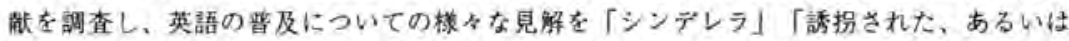

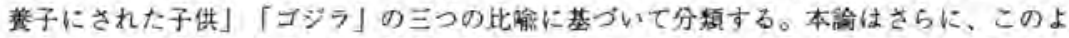
うな見解の多様性に由来する教育上の問題のいくつかに焦点を当て、それらが日本の英語

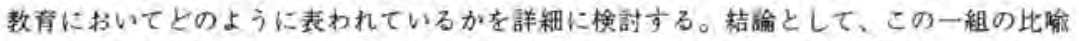

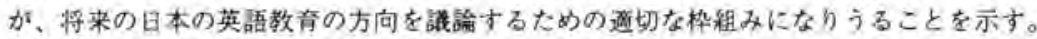

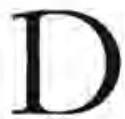

ivergent voices have been raised in response to the accelerated spread of English towards the end of the 20th century. Some people have rejoiced at the appearance of the first truly global language in human history, expecting that it will perform a more and more important function in further internationalizing society. Others have focused on the diversification of the language, one side worrying about what it sees as fragmentation and insisting upon the importance of maintaining Standard English but the other side positively recognizing this diversification and acknowledging the ownership of the language by non-native speakers. Still others have focused on the darker, aggressive side of its expansion, warning that the growing hegemony of English can be dangerous and harmful. The use of metaphors may help us put 
this complicated situation in perspective. As Lakoff and Johnson (1980) suggest, metaphors structure how we perceive and how we think, and they have the power to define reality.

\section{English as Cinderella}

An implication of this metaphor should be clear to everyone: The rise of English can be seen as an amazing success story. Originally English was only a small dialect brought to Britain by Anglo-Saxons in the 5th century, but now it has attained the status of the world's most common language. This is mainly because of the power of the British Empire in the 18th and 19th centuries and the influence of the United States in the 20 th century. Today it is "more widely scattered, more widely spoken and written, than any other language has ever been" (McCrum, Cran, \& MacNeil, 1986, p. 19), and it is called by various names, such as "the universal language," "the world's lingua franca," "a universally accepted world language," or "the language of the planet." A huge body of literature gives detailed accounts for this apparent linguistic miracle (e.g., Bryson, 1990; Crystal, 1988, 1997a, 1997b; Graddol, 1997; Graddol, Leith, \& Swann, 1996; Hirano, 1999; McCrum et al., 1986; Quirk \& Stien, 1990).

Let's take a very brief look at the numerical data Crystal (1997a) presents. In the reign of Queen Elizabeth I (1558-1603), the number of English speakers was between five and seven million, while by the beginning of the reign of Queen Elizabeth $\mathrm{Il}$ in 1952, the number grew fiftyfold to 250 million. Now, at the end of the 20 th century, it is far over 300 million. These are just the numbers of native speakers. Crystal estimates that there are 150 to 300 million speakers in the Outer Circle and 100 to 1000 million in the Expanding Circle, in accordance with Kachru's (1985) three concentric circles representing different ways in which English is used: the Inner Circle as L1, the Outer Circle as L2, and the Expanding Circle as EFL.

The success does not only mean an increase in the number of speakers. The uses of English vary tremendously. It is the most widely used language for international commerce, diplomacy, popular arts, and sports events. It is the leading language of science, medicine, technology, and academic conferences and publications. More recently, it is the dominant language for computer hardware, software, networking, and email. In short, English is an important language because of its "vehicular load" (Kachru \& Quirk, 1981, XV).

English as Cinderella also represents great expectations for the future role of the language. As the reader of the fairy tale naturally believes that Cinderella will become a wise and merciful princess and bring 
happiness to everyone in her realm, many people expect that the greater spread of English will be beneficial for the world because it will promote mutual understanding and cooperation worldwide and thus contribute to welfare and peace in the global village. Such high expectations are expressed in various ways. For example, Krishnaswamy and Aziz (1983) say that it is our good fortune that we have English as a candidate for a much-needed international auxiliary language, and we should not let this opportunity escape. Shaw (1983) says that the world has finally decided to fully accept the gift the British have given it. McConell (1995) says that with English one can become a global citizen. Of course, it is worth noting, as we will see later, that there are people who are skeptical about the future of the language. Graddol (1997) says "the future of English is more complex and less predictable than has usually been assured" (p. 1).

\section{English as a Kidnapped or Adopted Child}

The spread of a language leads to its diversification. Today it is common knowledge that there are numerous varieties of English, not only British English, American English, or Australian English but also socalled New Englishes such as Indian English, South African English, Nigerian English, Singapore English, and Hong Kong English. In addition, it is often said that other new Englishes such as Korean English or Japanese English are being formed in the Expanding Circle. Thus, the concept of English is extremely diverse, probably more diverse than any single language has ever been (McArthur, 1998). Numerous publications have documented this diversity (e.g., Bailey, 1991; Cheshire, 1991; Honna, 1990; Kachru, 1986; McArthur, 1998; Trudgill \& Hannah, 1982).

English can be seen as a kidnapped child for some native speakers who mourn the loss of its exclusive ownership. They deplore changes or "degenerations" and "corruptions" that the language is going through and want to retrieve "parental authority" based on the feeling that the language is theirs by historical right. They also feel anxious that it will change into unidentifiable different forms. Indeed, many observers express concerns that if English continues to develop at this pace, it will split further apart and eventually separate into mutually incomprehensible languages. Even now, according to McArthur (1998), "incomprehension (whether mutual or in one direction) is a common state within English as a world language" (p. xiv),

Such concerns naturally lead to the renewed recognition of the importance of Standard English. Quirk (1993) argues against the currently popular idea that any kind of English is as good as any other and em- 
phasizes the necessity to maintain Standard or institutionalized English. Taking a similar position, Widdowson (1994) asserts that the language must be protected and preserved and changes must be seen not only as peripheral but also as radial and traceable back to the stable center of the standard, otherwise things will fall apart. From the standpoint that language is power, Honey (1997) insists that seemingly egalitarian notions of New Englishes actually hold back language learners, denying them access to Standard English and hindering opportunities it makes available.

On the other hand, English can be seen as an adopted child for many non-native speakers who make full use of it in their daily lives and claim as their own. Data showing that the number of people who speak English as a second language will soon exceed the number of native speakers, and the far larger number of speakers in the Expanding Circle (see Crystal, 1997a; Graddol, 1997) suggest that English is now used in various parts of the world more frequently in the absence of native speakers than in their presence. In countries with multilingual populations such as India and the Philippines, not only is it used as a convenient means of communication, but it also functions to help unify the nation. Thus, it is natural for non-native English speakers in various social contexts to say, "Since we have adopted this child, we have the right to foster her in whatever way we want to,"

One extreme version of this view can be found in leading black South African academic Njabulo Ndebele's (1987) statement that the very concept of an international or world language is an invention of Western imperialism. He suggests that "South African English must be open to the possibility of its becoming a new language" and that "this may happen not only at the level of vocabulary, but also with regard to grammatical adjustments that may result from the proximity of English to indigenous African Languages" (p. 13). This view may be too radical for many to accept since he implies that linguistic changes should be made intentionally, but the basic attitude of speakers of New Englishes who regard the language as a part of their cultural heritage and as a means to express their ethnic identity is supported and encouraged by many ELT professionals (e.g., Kachru, 1983, 1986; Kirkpatrick, 1998; Nelson, 1992).

Turning to the educational literature published in Japan, we can find various comments and proposals that give support for the diversification of English. The leading linguist Suzuki Takao (1975, 1985, 1999) insists that Japanese people should learn English primarily as a means of sending information about Japan to the world. He claims that it is not English but "Englic," a kind of international auxiliary language that Japanese should try to acquire, and that certain characteristics of Japanese 
English should be internationally recognized and accepted. Writer Oda Makoto and interpreter and former member of the House of Councilors Kunihiro Masao take a similar position. Oda (1976) proposes that "Englanto," a word coined from English and Esperanto, should be widely promoted, and Kunihiro $(1972,1999)$ emphasizes the importance of learning to use simplified and de-Anglo-Americanized English, likening it to a kind of Morse Code. In the field of sociolinguistics, Honna Nobuyuki (1990, 1993), the chief editor of Asian Englishes since 1998, has conducted extensive research on varieties of Asian Englishes and their linguistic and functional characteristics. He considers the possibility that English as an Asian language can play a more important role in communication among Asian people.

In summary, the pair of metaphors, "kidnapped" and "adopted," symbolizes the conflict between maintaining a central standard of English and acknowledging different varieties as legitimate forms in their own right. In reality, this may be all a matter of degree, but in principle, the dilemma is sticky, because the former view in its extremely conservative form would inevitably lead to an ideological assertion that one variety (perhaps British or American) is superior to any other one, while the latter view in its extremely liberal pluralist form would promote further drastic diversification and as a result frustrate the very purpose of having a means for international communication. While Crystal (1997a) offers a certain prospect for the appearance of "World Standard Spoken English," Graddol (1997) implies that it would be too optimistic to expect that a single world standard will naturally develop, forming a supranational variety which must be learned by global citizens of the 21 st century. At present, it might be comforting to believe Strevens' (1982) rather simplistic statement that "as long as teachers continue to teach the lexico-grammar of 'educated/educational English,' the unity of the language will transcend its immense diversity" (p. 40).

\section{English as the Monster Godzilla}

What is an attractive princess or a dear child to some people can be a terrible monster to others. Just as Godzilla emerges from the sea onto land and destroys people and property, English crosses the oceans and damages other languages and cultures.

It is true that there are many factors behind the spread of a language throughout the world, but no one can deny that one of the most important factors is the political, especially military, power of people who speak the language. The image of English as Godzilla is most prominently associated with historical events in the process of the expansion 
of the British Empire. In essence, to quote Dissanayake (1993), "English was introduced to the British colonies in Asia, Africa and the Caribbean as a vital appendage of British colonial rule, one that was to be used as an instrument of oppression, alienation and marginalization of the indigenous peoples" (p. 336). For many of those colonized and subjugated, English was nothing but a threat, and it is no wonder that such a horrible image still strongly persists.

English as Godzilla represents not only the past memories of oppressive colonial experiences but also recent public sentiment against the continued spread of English. As negative effects of the globalization of English that can be identified from anecdotal evidence and observations, Alexander (1999) lists such effects as "being compelled to buy into Anglo-Saxon imperial ideology," "McDonaldization," "belittling of a person's native language," and "undermining indigenous native tongues and cultures through dissemination of implicit values" (p. 33). In fact, as is well known, France has laws banning the use of English in certain public domains, and anti-English movements can be observed in many other countries such as Germany, Mexico, Myanmar, and India (see Crystal, 1997b).

There may be nothing new about protests against a dominant language or language conflicts in general. What we must pay close attention to is that in the past decade critical views on English throughout the world have been presented by English language scholars and ELT professionals.

The most influential publication here is Phillipson's (1992) Linguistic Imperialism, which reveals the inner structure of the empire of the English language as the successor of the British Empire. By analyzing numerous documents of the British Council and other organizations, he demonstrates that it has been a deliberate policy of the British and American governments to promote and perpetuate the worldwide use of English for their economic and political advantages, and that, in order to achieve this purpose, self-serving tenets of ELT have been established and myths about the special values and usefulness of the language created. Thus, according to his account, the current status of English is not a natural consequence of world forces but a result of the success of the policy. Phillipson's critical standpoint is based on the idea of linguistic equality elaborated in Linguistic Human Rights (SkutnabbKangas \& Phillipson, 1994).

Sharing Phillipson's critical perspective, Pennycook $(1994,1995)$ argues against the dominant English-as-an-international-language discourse that considers its spread to be natural, neutral, and beneficial, and he examines social, cultural, economic, and political implications of the 
hegemony of English in view of a whole system of power/knowledge relationships. Pennycook (1998) also closely examines the colonial origins of the dominant discourse on the current status of English and demonstrates that colonial discourses still permeate applied linguistics and ELT. The permeation of colonial discourse into ELT literature is also identified and analyzed by Susser (1998) and Kubota (1999) in terms of the concept of Othering.

In this decade in Japan as well, some scholars in the field of English studies and education have raised strongly critical voices against the dominance of English. For example, the international communication specialist Tsuda Yukio $(1990,1996)$ perceives the dominance of English as something to be resisted. He criticizes not only native speakers' tendency to view English as an intrinsically valuable and useful language but also Japanese people's predisposition to accept such a view blindly, using such terms as "English conversation syndrome" or "English complex." As a token of resistance, he holds up the principle of equality in communication and proposes the establishment of international communication treaties to guarantee the use of one's mother tongue at international conferences.

Furthermore, sociolinguist and educator Nakamura Kei $(1989,1993)$ defines social characteristics of English as invasive and aggressive and from this viewpoint traces the process of the expansion of English within the British Isles and into African and Asian countries. He also analyzes Japanese English education in terms of systems, textbooks, and examinations. He points out that the system is based upon the ideological assumption that English and English culture are superior to other languages and cultures.

Moreover, English literature researcher Ohishi Shunichi (1990, 1994, 1997) grasps the problem of English imperialism in the macro-historical context of the West ruling the East, referring to Edward Said and various other post-colonial and post-modernist writers. For him, the worldwide dominance of English is a matter not only for sociolinguistics but also for specialists in philosophy and contemporary thought. From this perspective, he attempts to deconstruct myths of English, urges multilingualism, and aspires to the linguistic utopianism expressed in the novels by James Joyce.

\section{Pedagogical Conflicts}

The unprecedented spread of a language and its manifold uses naturally requires the reconsideration of established ideas of language and language education. The diverse perspectives of English described above 
are interrelated with various issues of English teaching in different parts of the world today. This part of the paper will highlight some pedagogical conflicts derived from these diverse perspectives and closely examine how such conflicts are reflected in the teaching of English in the Japanese education system.

\section{Conflicting Models}

One pedagogical conflict that has become conspicuous with the emergence of newly identified forms of English involves models for teaching English. The conflict is typically expressed by Strevens' (1981) question: "If Educational Nigerian English exists as a recognizable, identifiable entity, should that form become the model and target used in teaching of English in the schools of Nigeria?" ( $p$. 4). Strevens does not give a simple answer to this question, but undoubtedly the assumption that only British or American Standard English can or should be the authoritative model for every learner is increasingly questioned. According to Kachru (1986), a new, dynamic approach for the teaching of English around the world entails the "rejection of a native monomodel concept and acceptance of a polymodel concept" (p. 115).

For English education in Japan as well, the polymodel concept seems to be becoming important because its overall objective is obviously shifting from learning about the UK and the USA to acquiring a means for communicating with people from various parts of the world. However, which variety in addition to British and American English should be accepted as a model for Japanese learners is a complicated question. Some people say that Japanese should learn "International English" (kokusai eigo), but such an idea makes little sense in terms of the choice of a model because nobody speaks "International English" as a codified form of English. Honna and Takeshita (1998) criticize Japan's attraction to native speaker English, especially Anglo-American English, and urge the importance of developing learners' confidence in Japanese English, regarding it as a legitimate variety. Though confidence in its general sense is important, it is highly questionable whether Japanese English can be identified as a legitimate variety. At least it can not be paralleled with Indian English or Nigerian English.

This question is also related to whether or not, or to what extent, other Asian varieties of English should be incorporated in teaching English in Japan. On the assumption that English is an important means for communication among Asian people, it would be legitimate to claim that Japanese students should learn or at least familiarize themselves with these varieties. Honna and Takeshita (1998) also report how the city of Yokohama is employing people from such countries as Sri Lanka, 
Malaysia, and Singapore as temporary assistant teachers whose job is to introduce and discuss their countries in English. Should more English teachers from various Asian countries be invited to Japanese schools in the JET program or other future projects? This is a highly controversial issue.

\section{The Place of Culture}

The conflict about models leads to a more fundamental, theoretical question: the question of the relationship between language and culture. The notion that a language and its culture should be taught together because they are inextricably related entities has been widely supported by language teachers. Crawford-Lange and Lange (1984), for instance, emphasize that "to study language without studying the culture of native speakers of the language is a lifeless endeavor" (p. 140). However, such a notion is now being challenged as a result of the spread of English and the diversification of purposes for learning the language. Many researchers insist that English can or should be separated from the culture of traditionally English speaking countries or their people and elaborate the rationale for using local or international cultural contexts for effective teaching, especially in EFL or EIL (English as an International Language) circumstances (e.g., Alptekin \& Alptekin, 1984; Holliday, 1994; Kirkpatrick, 1998; Li, 1998; Prodromou, 1992). This suggests that the conventional cultural underpinnings of English teaching must be thoroughly reexamined.

Differences in views on the relationship between language and culture can be observed in the way university English teachers in Japan choose materials. Traditionally most Japanese university teachers have used English literature. In this case, teaching English is essentially connected with what is perceived as teaching English culture, often referred to as "Culture with a capital C." In recent years, the situation is rapidly changing, but the fundamental concept that teaching the socio-cultural norms and values of British and American people is an important part of English education can be seen in operation at universities throughout Japan. At the same time, however, there is a growing number of teachers who do not see English bound to Anglo-American culture, and they tend to choose materials with wider cultural content, more reflective of world cultures or global issues such as environmental problems or human rights problems (e.g., Akagi \& Shima, 1998; Arai, 1998). A good example of such materials can be found in those developed by Cates (1999), who emphasizes the importance of the linkage berween English education and global education. On the other hand, this is countered with the view that future Japanese English education should aim at 
enhancing learners' ability to explain Japanese culture and values to foreigners. Suzuki (1999) strongly proposes that English lessons should center on "things Japanese," with emphasis on translation practice from Japanese to English of literary texts and other social and historical documents. In his view, this is extremely important to shift the foreign language education paradigm from a receiver-type to a sender-type,

Though the development of cross-cultural understanding or awareness is often set forth as an objective of English education in Japan, it seems that classroom practices are too diverse or even confusing. The concept of culture is, of course, inherently difficult to define, As Mills (quoted in Holliday, 1994) states, it is "one of the spongiest words" (p. 21), but what is important to recognize here is that the spread of English is making the definition of culture in language education more and more complicated. Should English, as typically taught in an EFL setting like Japan, be considered as a language bound to Anglo-American JudeoChristian culture or as a language separable from it? In the latter view, should English be perceived as a culturally neutral medium for the conveyance of information or as a language already representing many cultures of people who speak New Englishes in various parts of the world? If so, how can such cultures be aptly incorporated in a classroom? These theoretical questions have important practical implications that necessitate English teachers to review what they have been doing.

\section{Negative Effects of Teaching English}

Finally, there is another pedagogical conflict derived from the view of English as Godzilla. Norton (1997) poses the direct question: "Are TESOL educators perpetuating Western imperialism in different parts of the world?" ( $p$ 425), commenting that it is a question under vigorous debate in the field of TESOL. Obviously this question is at the crux of the linguistic imperialism arguments. In response to this, Phillipson (1992) urges the reexamination of ELT from a macro social and political perspective, and Pennycook (1994) advocates a critical pedagogy that helps learners form a counter-discourse to the dominant discourse of English through English.

Since Japan survived the imperialism of the late 19th century without being colonized, and the native language has never been seriously threatened, one may say that fears of cultural invasions and the perpetuation of Western imperialism through English are misplaced. However, Tsuda (1996) and Nakamura (1996) point out that evidence of Japan's mental colonization can be found in the voluntary appropriation of numerous English words via katakana. According to them, this appropriation is often not only unnecessary but also even obscene in the sense that it 
represents a willful denial of Japanese identity. Though it is hard to tell whether or not, or to what extent, such a phenomenon can be attributed to English education at school, it is legitimate to think that English teachers have to be concerned about it.

Furthermore, it is important to note that English is de facto a compulsory subject in high schools and that it is the only foreign language for the vast majority of Japanese people to learn. Nakamura $(1993,1996)$ sees this extreme English-centeredness as a grave problem reflecting Japanese people's blind worship of English that leads them to disregard other languages and the people who speak them. Thus, he proposes the introduction of an elective system in Japanese school foreign language education, implying the necessity of reducing English hours in curricula. Such a proposal inevitably involves some inner conflict for English teachers.

\section{Conclusion}

English can be Cinderella, a kidnapped or adopted child, or the monster Godzilla, depending upon how one perceives it. This set of metaphors makes us acutely aware of the unprecedented sociolinguistic reality created by the spread of English throughout the world and of the existence of diverse perspectives on English as an international language. It also helps us to reexamine the relationships among language, power, culture, and identity and to think about various problems and conflicts in teaching and learning the language. In this light, I suggest that the set of metaphors can provide a good framework for discussing the future direction of English education in Japan.

At present in Japan there are various important issues related to English education. A hot social issue concerns the opinion expressed by the Prime Minister's advisors at the beginning of 2000 on the future possibility of adopting English as the second official language of the nation. The pros and cons on this opinion have been widely discussed. Different voices have also been raised about the basic guidelines issued by the Ministry of Education in 1997 for introducing English at elementary schools and redefining English as a required subject in junior high schools. Other important issues may include the place of English and other foreign languages as part of university liberal arts education after the deregulation of university curricula in 1991 and the roles of native English teachers and Japanese English teachers in the JET program, which has existed since 1987. A more general issue is the long-standing debate between those who insist upon the need to develop practical communication ability and those who support the conventional type of 
instruction based on the grammar-translation method as part of learners' intellectual training.

All of these issues are essentially related to the most fundamental question: "What is English for Japanese living in the world tomorrow?" I believe we as English teachers are responsible for fully discussing the question and presenting well-grounded opinions to the public and students. To fulfill such a responsibility, it is indispensable to deepen our understanding of the nature of English as a global language in a broad sociolinguistic perspective and to examine the implications for the Japanese in light of their own particular historical, social, cultural, and ideological background. I believe the set of metaphors around which 1 have centered this paper will be useful for such an inquiry. Only through thorough discussions can we overcome the incompatibility of diverse perspectives and gain a new perspective that is truly suitable for Japanese English education in the next century.

\section{Acknowledgements}

The autbor would like to thank James Porcaro, David Lobrey, and the two anonymous reviewers for their valuable suggestions and comments on earlier versions of this paper.

Hideo Horibe is an associate professor at Hiroshima Institute of Technology,

Note

1. At the 1998 JACET Conference in Okayama, Kip Cates introduced the three metaphors of English as Cinderella, a kidnapped baby, and Godzilla, which David Graddol originally used in his speech at the 1998 Conference of the English Teachers Association of Israel in Jerusalem. The author changed "baby" to "child," considering that English has already grown into "childhood," and added "an adopted child" as a metaphor representing the nonnative speaker's view

\section{References}

Akagi, Y., \& Shima, S. (1998). Eigo kyouiku niokeru chikyu shimin ishiki ikusei IHow to foster world citizenship awareness through Englishl. Paper presented at The JACET 37th Annual Convention, Okayama, Japan.

Alexander, R.J. (1999). Caught in a global English trap or liberated by a lingua franca? Unravelling some aims, claims, and dilemmas of the English teaching profession, In C. Gnutzmann (Ed.), Teaching and learning English as a global language: Native and non-native perspectives (pp. 23-39). Tübingen: StauffenburgVerlag.

Alptekin, C., \& Alptekin, M. (1984). The question of culture: EFL teaching in non-English-speaking countries. ELT Journal, 38 (1), 14-20.

Arai, K. (1998). Chikyu shimin shakai niokeru eigo kyoutku IEnglish education 
for a citizen of the world]. Paper presented at The JACET 37th Annual Convention, Okayama, Japan.

Bailey, R.W. (1991). Images of Englisb: A cultural history of the language. Cambridge; Cambridge University Press.

Bryson, B. (1990). The mother tongue: The English language. London: Hamish Hamilton.

Cates, K. (1999). Teaching English for world citizenship: Key content areas, The Language Teacher, 23 (2), 11-14.

Cheshire, J. (Ed). (1991). English around the world: Sociolinguistic perspectives. Cambridge: Cambridge University Press.

Crawford-Lange, L.M., \& Lange, D.L. (1984). Doing the unthinkable in the second-language classroom: A process for the integration of language and culture, In T, V. Higgs (Ed,), Teaching for proficiency: The organizing principle (pp. 139-177). Lincolnwood, IL: National Textbook Company.

Crystal, D. (1988). The English language. Penguin Books.

Crystal, D. (1997a). English as a global language Cambridge: Cambridge University Press.

Crystal, D. (1997b). The Cambridge encyclopedia of language (2nd ed.). Cambridge: Cambridge University Press.

Dissanayake, W. (1993). Perspective 1: Symposium on linguistic imperialism. World Englishes, 12 (3), 336-341.

Graddol, D, (1997). The future of English? London: British Council.

Graddol, D., Leith, D., \& Swann, J (Eds.). (1996). Englisb: History, diversity and change. London and New York: Routledge.

Hirano, J. (1999), Eigo monogatari (The story of Englishl Tokyo: Chukei Shuppan. Holliday, A. (1994). Appropriate metbodology and social context. Cambridge: Cambridge University Press,

Honey, J. (1997). Language is power: The story of Standard English and its enemies, London: Faber and Faber Ltd.

Honna, N. (Ed). (1990), Asia no eigo [Varieties of English in Asia]. Tokyo: Kuroshio Shuppan.

Honna, N. (1993), Bunka o koeta tsutaeat [Communication beyond culture]. Tokyo: Kaisei Shuppan.

Honna, N. \& Takeshita, Y. (1998), On Japan's propensity for native speaker English: A change in sight Asian Englishes, 1 (1), 117-137.

Kachru, B. B. (1983). Models for non-native Englishes. In L. E. Smith (ed.), Readings in English as an international language (pp. 69-86). Oxford: Pergamon Institute of English.

Kachru, B. B. (1985). Standards, codification and sociolinguistic realism The English language in the Outer Circle. In R. Quirk \& H. G. Widdowson (Eds), English in the world: Teaching and learning the language and tiferatures (pp. 11-30), Cambridge: Cambridge University Press.

Kachru, B.B. (1986). The alchemy of English: The spread, functions and models of non-native Englishes. Oxford: Pergamon Institute of English.

Kachru, B, B., \& Quirk, R. (1981), Introduction. In L. E. Smith (Ed), English for cross-cultural communication (pp. xiii-xx). London: Macmillan. 
Kirkpatrick, A (1998). Which language, which culture? Regional Englishes in contemporary Asia. Asian Englishes, 1 (2), 76 - 85.

Krishnaswamy N., \& Aziz, S. A. (1983). Understanding values, TEIL and the third world. In L. E. Smith (Ed.), Readings in English as an international language (pp. 95-102). Oxford: Pergamon Institute of English.

Kubota, R. (1999) Japanese culture constructed by discourses: Implications for applied linguistics research and ELT. TESOL Quarterly, 33, 9-35.

Kunihiro, M. (1972). Kokusai eigo no susume IRecommendation of international English]. Tokyo: Jitsugyou no Nipponsha.

Kunihiro, M. (1999). Messages from the persons of this month (interview). Jijieigo Kenkyu 53 (12). Tokyo: Kenkyusha.

Lakoff, G., \& Johnson, M. (1980), Metaphors we live by. Chicago: University of Chicago Press.

Li, David C. S. (1998). Incorporating L1 Pragmatic norms and cultural values in L2: Developing English language curriculum for EIL in the Asia-Pacific Region. Asian Englishes, 1 (1), 31-50.

McArthur, Y. (1998). The English languages. Cambridge: Cambridge University Press.

McConell, J, (1995), English and many cultures: Tokyo: Seibido

McCrum, R, Cran, W, \& MacNeil, R. (1986). The story of English. Penguin Books.

Nakamura, K. (1989). Eigo towa donna gengoka (What kind of language is English]? Tokyo: Sanseido.

Nakamura, K. (1993). Gaikokugo kyouiku to ideology. [Foreign language education and ideologyl. Tokyo: Kindai-bungeisha,

Nakamura. K. (1996). Dai 2, Dai 3 no gaikokugo [The second or the third foreign languagel. Eigo Kyoiku, June, 14-16. Tokyo: Taishukan.

Ndebele, N. S. (1987). The English language and social change in South Africa. English Academy Review, 4, 1-16.

Nelson, C. Li (1992). My language, your culture: Whose communication competence? In B. B. Kachru (Ed.), The other tongue: English across cultures (2nd. ed.) (pp. 327-339). Urbana, IL: University of Illinois Press.

Norton, B. (1997). Language, identity, and the ownership of English. TESOL Quarterly, 31, 409-429.

Oda, M. (1976). Eigo sosbite kotoba ni tsuite [On English and language]. In S Ishii (Ed) Shinban: Dougu toshite no eigo [New edition: English as a tool], (pp. 16-35). Tokyo: JIC Shuppan.

Ohishi, S. (1990). "Eigo" ideology o tou [Questioning "English" ideologyl. Tokyo: Kaibunsha.

Ohishi, S. (1994). "Eikoku" shinwa no kaitat (The deconstruction of myths of Englandl. Tokyo: Daisanshokan.

Ohishi, S. (1997). Eigo teikokushugi ron [On English imperialism]. Tokyo: Kindaibungeisha.

Pennycook, A. (1994). The cultural politics of English as an international language. New York: Longman.

Pennycook, A. (1995). English in the world/the world in English. In J. W. Tollefson (Ed.), Power and inequality in language education (pp. 34-58). Cambridge 
Cambridge University Press.

Pennycook, A. (1998). English and the discourse of colonialism. London and New York: Routledge.

Philipson. R. (1992). Linguistic imperialism. Oxford: Oxford University Press. Prodromou, L. (1992). What culture? Which culture?: Cross-cultural factors in language learning. ELT Journal, 46 (1), 39-50.

Quirk, R. (1993). English as a world language. In Y. Ikegami \& M. Toyota (Eds.), Aspects of Englisb as a world language (pp. 9-22). Tokyo: Maruzen.

Quirk. R, \& Stien, G, (1990). English in use. New York: Longman.

Shaw, W.D. (1983). Asian student attitudes toward English. In L. E. Smith (Ed), Readings in English as an international language (pp. 21-34). Oxford: Pergamon Institute of English.

Skutnabb-Kangas, T, \& Phillipson, R. (1994). Linguistic buman rights: Overcoming linguistic discrimination. Berlin and New York: Mouton de Gruyter.

Strevens, P. (1981). Forms of English: An analysis of the variables. In L. E. Smith (Ed.), English for cross-cultural communication (pp, 1-14), London: Macmillan. Strevens, P. (1982). English as an international language: Directions in the 1990s. In B.B. Kachru (Ed.), The other tongue: English across cultures (pp. 27-47). Urbana, IL: University of llinois Press.

Susser, B. (1998). EFL's othering of Japan: Orientation in English language teaching. JALT Journal, 20, 49-82.

Suzuki, T. (1975). Tozasareta gengo: Nibongo no sekai lA closed language: The world of Japanese]. Tokyo: Shincho-sensho.

Suzuki, T. (1985). Buki tosbiteno kotoba [Language as a weapon]. Tokyo: Shinchosha.

Suzuki, T. (1999). Nibonjin wa naze eigo ga dekinaika (Why are Japanese poor at Englishl? Tokyo: Iwanami-shoten.

Trudgill, P., \& Hannah, J. (1982). International English: A guide to the varieties of Standard English. London: Edward Arnold.

Tsuda, Y. (1990). Eigo shibai no kouzou tThe structure of the dominance of English] Tokyo: Daisanshokan.

Tsuda, Y. (1996). Shinryakusuru eigo: Hangekisuru nibongo [Invading Engtish and defending Japanese]. Tokyo: PHP kenkyusho.

Widdowson, H. G. (1994). The ownership of English. TESOL Quarterly, 28, 377 389

(Received December 7, 1999; revised June 27, 2000) 